\title{
The Efficacy of Davōnī's Philosophical Thought on Mullōșadrā's Opinions on the Issues of Principality, Making and Causation Based on The Theory of Tasting of Theosophy
}

\section{Yazdi Hossein}

Ph.D. Student in Islamic Philosophy \& Theology, Department of Islamic Philosophy \& Theology, Science and Research Branch, Islamic Azad University, Tehran, Iran

\author{
Doi:10.5901/mjss.2016.v7n3s3p162
}

\section{Abstract}

In three issues there is a feasibility to make a relatedness between 'AllamahDavōnī and MullāṢadrā: principality of existence, making and causation. It may be possible to trace Davānì's thought in MullāSadrā's philosophy from the existence as a singlesubsisting matter to the gradation of being, from the absolute being (wujûd-i muțlaq) to the concept of existence, from the existing quiddity being made to the making of the reality of being, and from the inhering existence to the connective being on the issue of causation.

Keywords: existence, making, causation, inhering existence, connective being.

\section{Davōini and the theory of principality}

Finding Jalâl ad-DînDavānīs opinion on the external distinction between the existence and quiddityis one of the important discussions. Because it is a central issue concerning principality of existence, quiddity and the divisions of the existence.

\subsection{Davānī and two peripatetic and illuminationist schools}

The issue of principality of existence and the quiddityis minor apropos of the issue of the distinction between the existence and quiddity. It should be noted that principality of existence for the first was raised by Mullās Sadrā after Davānīs era in a philosophical issue in the sphere of thought of philosophy.

Davōni who has emerged after the period of two peripatetic and illuminationist schools maintains that the external occurrence invalidates the existence related to quiddity and believes the absolute-abstract being can only be extracted out of existing quiddities without external occurrence taken place and this absolute being is a formal concept and the existing quiddities are nothing but an quiddity that ascribed to the existent by necessity (wōjibal-wujūd) and is of no share of existence and the existence is only ascertained in the existent by necessity. As a result, it may be said that Davōnidoes not accept the distinction that the peripatetic school has maintained between the quiddity and the existence; therefore, he raises the discussion of mental and external occurrence and otherness (zijyādat) of the existence and quiddity and believes that not external distinction is there between these two.

\subsection{Davōnī and the existence and its kinds}

Concerning the existence and its kinds, Davāni is of his own category based on specific attitude of his own. He believes in three matters: 1 . existence 2. existent 3 intelligible of existence. Davānī maintains that the existence is a singlesubsisting matter and an external truth which is the origin of derivation of existents.

Davōnī maintains that "the existent" is more general of the very external-single-subsisting truth as well as matters imputed to that external-subsisting-single truth. The other interpretation of Davōni of the existent is the particular being which consists of existent by necessity and possible existent (mumkinal-wujūd). He believes the particular being of existent by necessity is the particular truth which is not analyzable into the existence and object in the mind. Along with accepting the existence and existent, he maintains another matter called "the intelligible of existence" and in his other interpretation "the absolute being" that is adapted to the concept of existence of MullāSadrā. Some people think that Davāni believes in the absolute being more common than necessity and contingens, and indeed, in his point of view, the absolute being equals the existent, whereas such a thing is not true at all. Davōni announces frankly that there is no 
absolute being in outside and maintains that there is an external reality in particular being.

\section{3 Șadr-ul-Muti'allihīnShīrāzī, the principality of existence and its subfolders and criticizing Davānī}

MullāS Sadrā is the creator of the theory of the principality of existence as a philosophical issue. Principality means having an external reality and extension in the extra-mental world while consideration is against it. In MullăS Sadrā's point of view, the reality of existence is coextensive with being, and in quiddity there is only confinement, and it is a non-existential matter that its representation is just possible in the mind. Davōni maintains that the principality is in the existent by necessity or the existence, however, in possibilities, what makes them realizing is mere attributing of their quiddity to the existent by necessity. Șadr-ul-Muti'allihīnShïräzīwho maintains that the principality is with existence and the realizing factor is the existence does not accept MullāṢadrā's theory.

Mullạ̧̄adrā believes the existence comprises of the existent by necessity and possible existent contrary to Davānī who believes the existence limited in the existent by necessity. At that, in Mullāṣadrä's philosophy, the existence and existent are one and the same, while in Davōniss thought, as stated in anticipation, the existence equals the existent by necessity and the existent comprises the existent by necessity and possible existent. In Davānîs view, the intelligible of existence is a mental and mentally-posited matter. Whereas Mullā̧Sadrā's philosophy also considers the concept of existence a mental and mentally-posited matter. Both philosophers are similar in believing that the concept of existence is related, but from the point of the author of the article it is impossible to consider Șadr-ul-Muti'allihīnShirräzils affected by Jalâl ad-DînDavōninn this connection, because Davānī's frame in believing that the concept of existence is related is due to lack of authenticity in possibilities and making a common matter related out of different matters, whereas, MullāSadrä's frame in maintaining that the concept of existence is related is due to the external reality of the existence and disability of crossing in the mind, hence, the mind makes a concept out of it and trusts, the very thing that later was called the philosophical-secondary intelligible.

Some of Mullā̧Sadrā's reasons for the principality of existence in all degrees of existence and impressions of the principality of existence from his point of view are following checked:

\subsection{Some of MullāS Sadrā's reasons on the principality of existence}

1. It necessitates for the thing caused to have a cognition with the cause. On the other hand it has been proven that the existent by necessity is similar to the existence and with no boundary. Hence,what is issued is the existence of objects not their universal quiddity, for there is no compatibility and similarity between the existent by necessity and the quiddity of possibilities.

2. If the existence is related and the quiddity is original, it will necessitate that infinite specific quiddity distinct from one another in an actual way occurs in the finite move in quantity and qualitywhich is an impossible matter, moreover, it necessitates that the move in quantity and quality becomes a set of corpora indivisible which is a null matter.

3. How would it be possible that the existence is related? Whereas it is an essential making. If it is possible to accept the making of existence, the principality will be with the existence owing to the attachment of the making to the existence.

\subsection{Some results based on the principality of existence}

1. The connective being of the thing caused

2. The qualification of quiddity to the existence

3. Only is the existence fulfilled in the external world

4. Theology

5. Gradation in the existence

6. Science

\section{Illuminationists and the issue of making}

The issue of making was raised by Suhrawardifor the first time;however, it was not raised as a separate discussion. Shaikh al- 'Ishraqmaintains that the effect of the Makeris primarily and essentially quiddity, furthermore, it is this very quiddity being made that would require the quiddity to be existed and its qualification to the existence without the Maker 
falsifies the existence and/or the qualificationof quiddity to the existence again, because the existence and the qualificationof quiddity to the existence are mentally-posited and intellectual matters and its instancesare the very quiddityderived out of it.

\subsection{Peripatetic philosophers and the issue of making}

Șadr-ul-Muti'allihinreasons that the thing caused must be similar to the cause, and inasmuch as the existent by necessity is like the existence, what diffuses out is existences of objects not their quiddity, because the existence of objects is similar to the essence of agent and Maker, he cites Avicenna's speech in Risalah al-'Ishq (Essay on Love) to emphasize the cognition between Maker and something made. He attributes causation and effect in various aspects of existences to Peripatetic philosophers and adduces witness Avicenna's saying in al-Ilahiyat (Theology) al-Shifa'purport that serving as the cause of existence. KhawajaNasir al-DīnTüsialso emphasizes that the existence is something made.

\subsection{Davōnī and something essentially made}

Davōnibelieves in two kinds of making: the originated and invented one. The originated making is "an object being made" which is a non-composite making and without any plurality which is idiomatically called what is meant by "be" as a perfect verb and/or the signification of simple whether-ness. However, the invented making is "an object being made to something" which is the composite making and needs something made and the governed thing in the making state like the effusion of form over the substance which is idiomatically what is meant by "be" as an imperfect verb and/or the signification of composite whether-nesses. Davōnīconsiders the something essentially made as the quiddity of existent and even believes predecessors have followed this very view in the discussion of something made. The important thing is that even Davāni denies the theory qualificationbeing made as well,the theory ascribed to the latter of Peripatetics. Davōni reasons that if he wants the qualification to be something made, there are other qualifications again between this qualification and the existence and also this qualification and the quiddity and to the finite that all of which must be something made which leads to non-realization due to infiniteness, therefore, qualification may not form the base of making. EventhoughDavōnibelieves that the realizing fact is to ascribe the quiddity of a contingent thing to the existence of the existent by necessity, he does not consider something made as this very relation.

\subsection{MullāṢadrā and the issue of making}

Based on Șadr-ul-MutiallihīnShirrāzìs thought, it is conspicuous according as the principality of existence and the quiddity being mentally-posited that something essentially made is the existence to the non-composite making and the meaning of existence is also the very reality of existence. Because,on the one hand, the cause-caused relationship, i.e. making-existentiation relationship, is a relationship between external realities so that an external reality creates the other external reality and the second reality is its action, impression and something made; and, on the other hand, external realities are not the type of quiddity according to the principality of existence and the quiddity being mentally-posited but are non-quidditivematters. As a result, something essentially made and the effect of the Maker is the reality of existence as the essential Maker is the reality of existence, namely an ontological truth is the impression and action of another ontological truth.

In other argument,Mullạ̧̄adrārejects the quiddity being something made and especially Davānīs idea and says: if quiddity requires the Maker according to its own entity, in this case, itwill be in need of the Maker within its own entity, moreover, the Maker will be authoritative in the subsistence of its entity, so that it will be impossible to imagine it without the Maker, whereas it is not so, because it is possible to imagine many quiddities with their definitions, although, there is doubt in their realization and acquisition let alone to be aware of acquisition of their Makers, for quiddity does not point to a thing other than itself.

\subsection{Davānī and the difference between connective being and inhering existence and the review of Mullāṣadrā}

Mullā̧Sadräbecomes finally and at the end of the discussion of the connective being and independent existence the believer that the only independent existent is God and other than Him everyone is the connective being.

Why MullāS Sadrāis different in his view with ancestors, he maintains that they consider the existence of possibilities as an existence inconsistent with the existence of existent by necessity and, nonetheless, they believe the existence of possibilities is somehow related to the existence of existent by necessity and maintain that this relation and ascription 
necessitates the contingent being. Whereas,from the point of Șadr-ul-Muti'allihīnShïrāzī, the possibility is imputed to the existent by necessity per se and not a redundant relation on its entity and it is mortal in the existent by necessity in its entity. Mullā̧Sadrā considers all things as similar to the connection to God.

\subsection{Davōnī and the issue of causation}

A) Davōni and the inhering existence of the thing caused

According to Davānīs point, it is not that the thing caused need two Makers in quiddity and its existence, but making belongs to the quiddity, and the existence is abstracted from the quiddity.

Another thing that proves the theory of connective being of the thing caused in Davāniss thought is the note and similitude that he mentions. As he says under the note that: "the thing caused related is not pure, and if it is considered in terms of its relation with the cause, it is of realization; furthermore, if it is considered as an independent entity off the cause, it will be non-existent and rather impossible."Davōnilikens the relation between the cause and the thing caused to the relation between accident and essence and says that if melanaemia is considered independence from the object, its existence will be impossible, however, if it is considered accidental for the object, it will be the existent.

\subsection{The review of MullāṢadrāon Davānī's opinion}

Referring to the topic that Peripatetic philosophers believe the existence of the thing caused is something made, while illumination scholars maintain that the quiddity of the thing caused is something made, in criticizing the second group that according to his interpretation Davānī and his pupils have considered it as the illumination scholars' view, Sadr-ulMuti'allihin says: the second group has thought that if something made is the existence of the thing caused, it will necessitate the Maker ascertain the existence of quiddity and give away essential parts to Him by the composite making, whereas it is no so, because there is a difference between the need by-itself and the need by accident, and the truth of essential parts upon the thingdo not need any making of the Maker, but making of essential parts depends on the entity, then, the making of entity and essential parts is done by a single making not the composite one. Thus, the different point of view between Davōnī and Mullāșadrā in the issue of making is that one believes that the existence of the thing caused is something made and the other maintains that the quiddity of the thing caused is so, nevertheless, there are consensus of opinions in this meaning that making of essential parts is not by the composite making but by the noncomposite one, that is, the very existence or quiddity that the agent makes is of that essential parts in itself.

MullāS Sadrābelieves two meanings of the connective being and the inhering existence have not been differentiated in Davānīs speech, for in that the object is black, there is no black in that it has been predicated given in answer to a composite whether-ness except in the sense that it is of a positiveness for the object and there is no hindrance that black has been of an existence in the composite whether-ness by the consideration of the other apart from the consideration of quality given, although, its existence in-itself is the very existence for the object.

As such, MullāṢadrāin this criticismdoes not consider the accident right in Davānīs thought on the inhering existence, but his criticism focused on the relation between the cause and the thing caused that its similitude to the relation between the accident and the person afflicted with accident requires the dictum to the connective inhering existence of the thing caused, inasmuch as the existence of the thing caused is the connective being from Mullāșadrā's point of view.

B) Davānī and the connective being of the thing caused

There are statements that show Davāni believes the thing caused is an aspect of aspects and the states of cause. In his view, causal ends up in a unique existent that the overall series are directly and/or indirectlyits thing caused. It is a real entity and the whole series are its states, modes and aspects. Then, what is in the world is not diverseentities but a unique entity that is of multiple attributes. The chronological extension which is also the place of change, transformation and arena of global events along with events therein is a state of states of the first cause and encompasses all states of the next.

\subsection{The review of MullāṢadrā on Davānìs opinion and approvaland affection}

Davānīs simile has faced with problems from MullāṢadrā's point of view, for line is not gradually mortal and acquired little by little unlike events, and there is its potential components as well. Davānīspoint of view that the thing caused is an aspect of aspects and a manifestation of manifestations of the cause requires a dictum to the personal unity of the existence, hence, it causes the negation of multiplicities, the thought that has been brought up in the works of great 
mystics such as Ibn 'Arabī, Kōshōnī, Qiyșarī, Jāmī, SayyidHaydarĀmulīand IbnTurk-ilsfahanī. Although Mullā Șadrāat the beginning becomes the believer of graded unity in which by accepting the real existence of multiplicities he considers them as graded hierarchies of existence of the divine unity, in the end he becomes the believer of the theory of particular unity of existence.So it is possible to speak according to the relationship which is or at least in some part between MullāṢadrā's view and Davōnī's in which causation is transformed into the issue of diversity and modality (tasha'un), and it may say that both of them have closed to mystics' view in this connection. Nonetheless, in any case, similar expressions in works of these two philosophers make the efficacy of Davōnī on MullāṢadrāShìrāzì probable. Some of his similar expressions are as follows:

Davāni says that if form is the concept, it will be different from the truth. MullāṢadrāalso neglects this part of alzawrā 'in Asfār and does not mention anything about it, whereas this view is compatible with the theory of particular unity of the existence in which MullāSSadrā believes.

\section{Causation in Mullāṣadrā's thought}

The assumption of categorical relation between God and possibilities is now out the question according toMullāSadrāin Asfär, because the categorical relation is one of the highest genera, inasmuch as the necessary existence is the mere existence and is not under the topic of relation.

He believes the relation of the existent by necessity with the world is not like the relation of the construction with the building or the relation of the writer with the writing, for both of them are the thing caused after the authorship of the agent and independent and self-sufficient of the agent.

Sadr-ul-Mutiallihinnsays on the authorship of God: God's authorship is the authorship by nature according as a group of Tabāiryyah and Dahrīyyūn, and it is the authorship by intention based on the majority of theologians. In this place, he accepts the existence of multiplicities as an evident matter and calls its denier a casuist,yet he becomes the believer of the particular unity of the existence at the end of the discussion of causation in Asfärand is at one with mystics, besides, he introduces possibilities as the states, aspects and modes of the necessary existence. Definitely, these two views are contradictions regarding to some contemporaries.

Șadr-ul-Muti'allihinnsays that all creatures such as the intellect, soul and form of the species are stages of rays of the true light and manifestations of God's subsistent existence.God bestowed me the demonstration of this meaning in accordance with His eternal grace. This principle is an exact, complex and difficult-detectable one.

In the theory of connective being, MulläS Sadrammaintains that the existence of possibilities is the same as the connection with the necessity and their need and poverty is one with the principle of their reality. Therefore, according as him, what is the yardstick of the need of the thing caused to the cause is this very poverty and need that is in the truth of an object which interpretsit as the poverty possibility or existential poverty.

\section{The summation ofthe impact of Davānīs reflection on Mullā Șadrā on the issue of causation}

Davānihas become afflicted with confusion between inhering existence and connective being in Resālatal-zawrā'on the existence of the thing caused, so that there are two indications to confirm the first one and two other onesfor the second one in the treatise. What confirms the statement of inhering existence is; one, his belief in quiddity being made which is compatible with principality of quiddity and the other is to likenthe relation between cause and effect to the relation between quiddity and non-essential quality and both of which are incident to the majority acceptance in the world. MullāS âdrā who maintains that the existence of the thing caused lies in the connective being criticizes Davānīs idea in Asfär.

However, what confirms the connective being of the thing caused in Resālatal-zawrä' is one; changing the issue of causation to the issue of diversity and modality (tasha'un) and believing that the thing caused is a state of states and an aspect of aspects of the cause, and the other is Davōnīs idea on the relation between the truth and intuitive knowledge, namelyhe maintains that the truth is an extensive and unique matter and what makes its multiplicity is its appearance in different levels of perception, therefore, sensory, imaginal and intellectualideas are nothing but manifestationsand epiphaniesof the truth. In Asfār, Mullāṣadrādoes not speak on this section of Resālatal-zawrā', perhaps because he does not see any controversy in it and accepts it, or because he maintains that it is incompatible with the principality of quiddity and believes that it is just enough to point merely at the occurrence of confusion between the connective being and inhering existence in Davānī's saying. In the beginning, MullāṢadrāadopts the concept of analogicity from Shaikh alIshraqandmaintains that it flows in the existence not in the quiddityand becomes a believer in the analogical gradation unity (vahdat-i tashkiki) of existence and accepts being of multiplicities in the world as a conspicuous matter; although, 
he approaches finally the theosophists' view and speaks on the personal unity of the existence. In this place, he negates independent existence of multiplicities and consider them as the divine light of manifestations. Davānimay be considered as the pioneer ofMullā̧Sadrā in assimilating philosophical thoughts and prescriptive-supreme themesin verses and traditions.

\section{References}

Āshtīyānī, Sayyid Jalâl ad-Dîn. (2001).MullāṢadrā’s biography and philosophical opinions. Qum:Daftar-i Tablīqāt-i Islāmī.

Ibn Sīnā, Husayn. (1997).Al-Nafs min Kitabush-shifā, literally means The Soul from the Book of Healing. Researched by Hassan Hasanzādih Ämulī. Qum:Daftar-i Tablīqāt-iHuwzih 'Ilmīyyah.

Javādī-Ämulī, Ayatollah.RahīiqMakhtūm;sharh-i al-hikmat al-muta'liyah (The explication of transcendent theosophy). Vol. 1, p. 320.

Davānī, Muḥammad bin As'ad. (2001).Ithbōt al-Wōjib al-Jadīdah (Sab“ Rasō'il). By Ahmad Tūyīsirkānī. Tehran: The Research Center of Mīrāth-i Maktūb.

Ibid. (2001). Ithbōt al-Wōjib al-Qadim (Sab`Rasō'ill).By Ahmad Tūyīsirkānī. Tehran: The Research Center of Mīrōth-i Maktūb.

Ibid. Al-Hāshhīyyah al-ajidd 'Alā al-Sharh al-Jadid lil-Tajrīd.Manuscript. Library of Islamic Consultative Assembly. No. 1999.

Ibid. The old version ofAl-Hāshīyyah 'Alā al-Sharh al-Tajrīd. Manuscript. Library of Islamic Consultative Assembly. No. 1753.

Ibid. 'Ilmun-nafs.Manuscript.Library of Āstān Quds Raḍavī.No. 1427.

Sabzavari, Mulla Hādī. Ghurar al-farā'id (known as Šarḥ al-manẓuma), p 87.

Șadr ad-Dīn Shīrāzī, Muḥammad bin Ibrahim [MullāṢadrā - Șadr-ul-Muti'allihīn] (1989). Al-Hikma al-muta'aliya fi-l-asfar al-'aqliyya alarba'a, or The Transcendent theosophy in the Four Journeys of the Intellect. Qum: al-Maktabah al-Muștafawī.

Mișbāḥ Yazdī, MuḥammadTaqī (1987).Tađİ̃ah 'AlāNihāyat al-hikmah. Qum: Dar Rāhi Ḥaq.

Ibid (2010). The commentary of $8^{\text {th }}$ volume of Asfär al-'arba'eh. Qum:Publications of Imam Khomeini Educational and Research Institute. Muțahharī, Murtị̄ā. Majmūith Āthār 11\&12 (Darshaye Asfōr). Tehran: Șadrō Publications.

Ibid (2001).Majmū ih Āthōr 5, $9 \& 10$ (Sharh -e- Manzume). Tehran: Șadrā Publications.

Ibid (1994).Majmūih Âthōrr 13 (Maghalate falsafi). Tehran: Șadrā Publications. 